\title{
POTRET KERJASAMA ANTARDAERAH DALAM PEMBANGUNAN INFRASTRUKTUR DAERAH
}

\author{
Teguh Budi Prasetya (teguhbudiprasetya@gmail.com) \\ Fakultas Isipol Universitas Proklamasi 45
}

\begin{abstract}
Local autonomy has implications for decentralization of development process of some public infrastructures. The problem from this context is inefficiency of the development of public infrastructures across regions. This is a result of non synchronizations of perceptions, priorities, and funding of inter-regional (city/district). As consequences, some public infrastructures across regions are difficult to be constructed. Various models of inter-regional cooperation have been implemented, but not many are giving good results. This paper will try to analyze some inter-regional cooperation forms in Central Java and Yogyakarta Special Region in order to see how far that has shown results. This paper is important because of inter-regional cooperation becomes a necessity that expected giving so many success.
\end{abstract}

Key words: cross-regional infrastructure, inter-regional cooperation, decentralization.

\section{PENDAHULUAN}

Otonomi daerah, sebagaimana diamanatkan Undang Undang No 25 Tahun 1999 yang kemudian direvisi dengan UU No 32 Tahun 2004 membawa implikasiterhadap desentralisasi pembangunan daerah. Artinya Daerah (Kabupaten/Kota) memiliki kewenangan dan kewajiban untuk merencanakan, melaksanakan termasuk membeayai pembangunan daerah. Demikaian pula dengan pembangunan infrastruktur publik seperti infrastruktur transportasi, komunikasi, air minum, pertanian dan infrastruktur ekonomi lainnya menjadi sangat tergantung dari proses perencanaan di daerah (kabupaten /kota).

Masalah kemudian muncul ketika infrastruktur publik yang harus dibangun bersifat lintas daerah. Artinya infrastruktur itu (bangunan fisik, pemanfaatan dan pemeliharaan nya) harus melintasi lebih dari satu daerah otonom. Tidak jarang muncul hambatan kewenangan, birokratis, administratif dan pendanaan ketika daerah-daerah yang dilintasi infrastruktur publik tidak memiliki kata sepakat. Akibatnya infrastruktur yang menjadi kebutuhan publik terhambat untuk dibangun. Kasus "Gagasan Megapolitan" untuk kawasan Ibukota (Kompas.com) yang kala itu digagas Gubernur DKI Sutiyoso adalah bentuk keputusasaan Pemda DKI menghadapi kenyataan bahwa infrastruktur jalan, kemacetan lalu lintas, pengendalian banjir dan pengelolaan sampah ternyata harus diselesaikan secara lintas daerah. Padahal menyamakan persepsi antar Daerah untuk membangun infrastruktur publik lintas daerah bukan hal yang mudah. Penelitian Murbanto Sinaga (2005), membuktikan ada kecenderungan Pemerintah Daerah berjalan sendiri-sendiri (egosentrisme daerah) dan tak mau berkordinasi dengan Pemda tetangga dalam pembangunan daerah. Kasus serupa misalnya adalah pembangunan Jalan antara MedanBinjai-Deli Serdang (Mebidang) (lihat M Sinaga:2006), dan pengadaan instalasi Air Bersih di Kota Yogyakarta serta Problem Tempat Pembuangan Akhir (TPA) Sampah di Kota 
Bandung; yang semakin menunjukkan dengan jelas bahwa ada persoalan pembangunan Infrastruktur lintas daerah yang dihadapi dalam era otonomi daerah dewasa ini.

Berbagai forum kerjasama antar daerah telah dirintis, misalnya Kartamantul (Yogyakarta-Sleman-Bantul), Mebidang (Medan-Binjai-DeliSerdang), Jratunseluna (JragungTuntang-Serang-Lusi-Juana), danJabodetabek (Jakarta-Bogor-Depok Tangerang-Bekasi). Namun hingga kini formum itu belum beranjak bangkit dari sekedar forum komunikasi antar daerah menjadi institusi yang efektif mengakselerasi pembangunan infrastruktur publik lintas daerah. Pemerintah Propinsi sendiri sering tidak mampu mengambil peran itu karena keterbatasan kewenangan dan terutama keterbatasan pendanaan yang dialami. Kajian tentang keberhasilan berbagai kerjasama antar daerah dapat menjadi referensi dalam menjalankan berbagai kerjasama antar daerah dalam membangun infrastruktur di waktu dan tempat yang berbeda.

Kajan ini akan dilakukan dengan mengambil kasus Kabupaten Cilacap, Daerah Istimewa Yogyakarta dan Kabupaten dan Kota Semarang. Kabupaten Cilacap mewakili Kabupaten kabupaten yang jauh dari bantuan Provinsi, Kabupaten/Kota Semarang mewakili daerah yang "dekat" dengan kekuasaan Provinsi, sedang DIY terdiri dari kabupaten/kota yang hubungan antar wilayahnya memiliki kesamaan kultur yang erat.

Data diperoleh dengan metode indepth interview terhadap para pemangku kepentingan, observasi wilayah dan memanfaatkan data sekunder yang ada di berbagai sumber. Pendanaan untuk medukung penelitian ini diperoleh dari Hibah PHB (Penelitian Hibah Bersaing) TA 2013.

\section{KAJIAN LITERATUR}

Otonomi daerah sebagai upaya memperbaiki kinerja birokrasi pemerintah daerah diawali dengan diterbitkannya UU No 22 tahun 1999 tentang Pemerintahan Daerah dan UU No 25 tahun 1999 tentang Perimbangan Keuangan Pusat dan Daerah. Pemerintah Daerah yang selama ini lebih banyak berperan menjadi kepanjangan tangan pemerintah pusat, tibatiba memiliki kewenangan besar dalam mengelola pembagunan daerah. Otonomi daerah menimbulkan besarnya harapan untuk mengkoreksi pembangunan yang selama ini dilakukan secara sentralistik.

Namun sayangnya, pesta tak berlangsung lama. Otonomi daerah yang diyakini publik sebagai solusi bangsa ini telah dianggap melenceng dari tujuan semula. Keluhan, kritik dan makian berkembang di berbagai forum seminar, media massa, kalangan perumus kebijakan dan pembicaraan sehari-hari masyarakat (Karim Abdul Gaffar: 2003) Opini ini nampaknya berkembang berkait dengan penilaian publik atas profil, perilaku dan kebijakan petinggi daerah selama ini iauh dari harapan (Pratikno:2007). Pratikno mengidentifikasi berbagai persoalan yang melanda otonomi daerah, seperti sinisme dan pesimisme atas profil dan kinerja DPRD, sinsime dan kekhawatiran lahirnya "raja-raja kecil" daerah yang bertindak semau gue, kinerja pelayanan publik yang tak kunjung membaik (Pratikto: 2007). Bahkan laporan Kompas (24 April 2009), menunjukkan betapa terbengkalainya Infrastruktur Publik di era otonomi daerah.

Namun yang paling penting dari semua "kegagalan" itu adalah lahirnya cara berfikir "kemasing-masingan" (Pratikno:2007), yakni cara pandang yang daerah sentris dalam menyikapi persoalan pembangunan. Cara pandang ini menjadi komplikatif ketika Daerah merespons persoalan-persoalan yang lebih luas; yakni persoalan yang tidak dapat diselesaikan secara parsial. Padahal berbagai persoalan, seringkali bersifat lintas daerah. Persoalan penanganan infrastruktur publik seperti DAS, jalan raya antar daerah, kanal pengendali banjir, instalasi air bersih dan limbah, dan transportasi pada kenyataannya selalu bersifat lintas daerah. Fakta ini kemudian menimbulkan persoalan ketika berhadapan 
dengan pemerintah daerah yang cenderung “inward looking”.(Pratikno 2004) Fenomena inilah yang kemudian dikatakan orang sebagai ironi otonomi daerah.

Solusinya adalah kerjasama antar daerah. Kerjasama antara daerah adalah perikatan antar dua atau lebih pemerintah daerah untuk mengatasi persoalan bersama. Kerja sama semacam ini niscaya harus dilaksanakan karena kenyataannya banyak persoalan ekonomi, sosial, budaya dan pelayanan publik yang bersifat lintas daerah. Kerjasama semacam ini mudah dilaksanakan (dipaksakan) ketika dominasi Pemerintah Pusat atas pemerintah daerah atas perencanaan dan pendanaan pembangunan masih kuat. Namun pada saat peran itu dilimpahkan kepada daerah; kerjasama yang mestinya menjadi keniscayaan tidaklah mudah dilakukan.

Menurut Pratikno (2004), ada beberapa alasan kuat atas terjalinnya kerjasama antar daerah itu: pertama, logika pengaturan cara lama yang didasarkan atas regulasi dan kontrol yang hierarkhis sudah tidak memadai dikarenakan sudah tersebarnya "kekuasaan" ke tangan banyak aktor (baca:pemerintah daerah) Kedua, peluang dan tantangan yang dihadapi pemerintah daerah seringkali bersifat lintas teritori. Ketiga, kerjasama antar daerah dapat memperkuat "posisi tawar" daerah tatkala harus berhadapan dengan aktor luar dan keempat, kerjasama antar daerah mampu mengatasi keterbatasan sumberdaya yang dimiliki. Dalam situasi demikian inilah, maka konsep "network governance" menemu kan konteksnya.

Di banyak negara, praktek intergovernmental network juga telah lama di praktikkan. SALGA (South Africa local Government) di Afrika Selatan, LCP (the League of Cities of Philippines) dan CoR (Commitee of The Regions) adalah kerja sama antar daerah yang telah eksis menyelesaikan berbagai persoalan yang dihadapi bersama.Di Indonesia, telah lama dikenalKartamantul (Yogyakarta, Sleman dan Bantul), Jabotabek (Jakarta Bogor Tangerang Bekasi), Mebidang (Medan Binjai Deli Serdang) adalah contoh-contoh networking antar daerah yanag telah di bentuk. (Pustra Dep. PU:2007).

Secara konseptual, penelitian Jurusan Ilmu Pemerintahan UGM dalam sebuah penelitiannya menyebutkan terdapat beberapa manfaat yang dapat diraih dalam kerjasama antar daerah:

a. Manajemen Konflik antar Daerah

b. Efisiensi dan Standardisasi Pelayanan Publik

c. Pengembangan Ekonomi;

d. Pengelolaan Lingkungan. (Pratikno dkk, JIP : 2007).

Secara umum persoalan antar daerah, termasuk infrastruktur publik amat beragam potret maupun sifatnya. Karena itu, basis yang dapat dipakai sebagai dasar kerjsama antar daerah juga bisa beraneka ragam; misalnya:

a. Basis ketetanggaan secara geografis.

Kesamaan geografis sering menjadi cermin kesamaan persoalan yang dihadapi secara bersama; sehingga basis ketetanggan georafis cukup kuat dijadikan alasan kerjasama.

b. Basis kesamaan potensi.

Kesamaan potensi antar daerah bisa menjadi tidak sehat tatkala menimbulkan konflik dan persaingan yang tidak sehat pula. Sebaliknya dengan bekerjasama, potensi yang dimiliki bisa dikelola bersama secara lebih efisien.

c. Basis kesetaraan permasalahan.

Biasanya kesamaan persoalan yang dihadapi antar daerah, dapat menjadi alasan yang kuat

Alasan lain yang dapat menjadi dasar kerjasama adalah "kesamaan kepentingan" atas sebuah persoalan yang dihadapi secara lintas daerah. Kesamaan kepentingan atas infrastruktur publik, seperti jalanraya, dermaga, transportasi, air bersih dan air limbah serta irigasi dapat saja menjadi basis pendirian sebuah forum kerjasama antar daerah. 
Bentuk dan metode kerjasama antar pemerintah daerah meliputi (1) intergovernmental service contract; (2) joint service agreement, dan (3) intergovernmental service transfer (lihat Henry, 1995). Jenis kerjasama yang pertama dilakukan bila suatu daerah membayar daerah yang lain untuk melaksanakan jenis pelayanan tertentu seperti penjara, pembuangan sampah, kontrol hewan atau ternak, penaksiran pajak. Jenis kerjasama yang kedua diatas biasanya dilakukan untuk menjalankan fungsi perencanaan, anggaran dan pemberian pelayanan tertentu kepada masyarakat daerah yang terlibat, misalnya dalam pengaturan perpustakaan wilayah, komunikasi antar polisi dan pemadam kebakaran, kontrol kebakaran, pembuangan sampah. Dan jenis kerjasama ketiga merupakan transfer permanen suatu tanggung jawab dari satu dearah ke daerah lain seperti bidang pekerjaan umum, prasarana dan sarana, kesehatan dan kesejahteraan, pemerintahan dan keuangan publik.

Sementrara itu dilihat dari derajat kerja sama antar daerah, dapat dipilah dua bentuk kerjasama. Yang pertama handshake Agreement dan writen agreemen. (Rosen dalam Yeremias T Keban 2007). Bentuk "handshake agreements" merupakan bentuk yang banyak menimbulkan konflik dan kesalahpahaman (misunderstanding), sementara bentuk yang tertulis dibutuhkan untuk melakukan program kontrak, kepemilikan bersama, atau usaha membangun unit pelayanan bersama. Hal-hal yang harus diucapkan dalam perjanjian tertulis ini meliputi kondisi untuk melakukan kerjasama dan penarikan diri, sharing biaya, lokasi, pemeliharaan, skedul, operasi dan aturan kepemilikan sumberdaya bersama, kondisi sewa, dan cara pemecahan konflik .

Rosen (1993: 218 - 222) menjelaskan bahwa pengaturan kerjasama antar pemerintah daerah terdiri atas beberapa bentuk; yaitu:

a. Consortia: yaitu pengaturan kerjasama dalam sharing sumberdaya,

b. Joint Purchasing: yaitu pengaturan kerjasama dalam melakukan pembelian barang agar dapat menekan biaya karena skala pembelian lebih besar.

c. Equipment Sharing: yaitu pengaturan kerjasama dalam sharing peralatan yang mahal, atau yang tidak setiap hari digunakan.

d. Cooperative Construction: yaitu pengaturan kerjasama dalam mendirikan bangunan, seperti pusat rekreasi, gedung perpustakaan, lokasi parkir, gedung pertunjukan, dsb.

e. Joint Services: yaitu pengaturan kerjasama dalam memberikan pelayanan publik,

f. Contract Services: yaitu pengaturan kerjasama dimana pihak yang satu mengontrak pihak yang lain untuk memberikan pelayanan tertentu,

g. Pengaturan lainnya: pengaturan kerjasama lain dapat dilakukan selama dapat menekan biaya, misalnya membuat pusat pendidikan dan pelatihan (DIKLAT), fasilitas pergudangan, dsb.

Kapasitas kerjasama antar daerah seringkali ditentukan oleh derajat sharing yang menjadi pilar terbentuknya kerja sama. Semakin tinggi sharing antar daerah dalam pola kerjasama, maka kerjasama yang dibangun akan memiliki kapasitas didalam mengatasi persoalan- persoalan yang dikerjasamakan. Oleh karena itu bisa dikatakan bahwa sharing sesungguhnya adalah inti dari kerjasama, bukannya manfaat yang selama ini banyak dipahami. Yudhoyono (2002), menjelaskan sharing dalam kerjasama antara lain berupa sharing of experience, sharing of benefit dan sharing of burden.

Faktor lain yang menentukan kapasitas kerjasama, adalah kemampuan mereka dalam mengkonversi sharing menjadi aksi bersama (collective antion). Hanya melalui mekanisme inilah maka kerjasama yang dibangun dapat dipakai sebagai instrumen untuk mengatasi persoalan, termasuk didalamnya adalah persoalan pembangunan infrastruktur lintas daerah. Dalam salah satu kajian yang dilakukan oleh Pusat Kajian Stretegis (Pustra) 
Dep. Pekerjaan Umum (2007) terungkap bahwa berbagai kerjasama antar daerah tak kunjung mampu merumuskan collective action untuk mengatasi persoalan lintas daerah. Oleh karena itu bisa dimengerti jika format kerjasama antar daerah saat ini masih dipandang sebagai "forum komunikasi" yang seringkali miskin aksi. (Pustra Dep.PU:2007).

Dalam format kerjasama antar daerah, collective action yang dikembangkan dapat berbeda satu dengan yang lain. Hal itu ditentukan oleh dua faktor utama, yakni tingkatan kordinasi dan derajat kesamaan kepentingan antar daerah / aktor yang terlibat dalam kerjasama. Lars Carrison (1995) menjelaskan fenomena itu dengan menyebutnya sebagai "The Logic oc collective action" sebagai berikut:

Tabel 1:

The Logic of Collective Action

\begin{tabular}{|l|l|l|l|}
\hline & \multicolumn{3}{|c|}{ Inter } \\
\hline \multirow{2}{*}{} & & Divergent & Commont \\
\cline { 2 - 4 } & Hig & Policy Network & Organization \\
\cline { 2 - 4 } & Lo & Election & Riot \\
\hline
\end{tabular}

Sumber: Lars Carrison:1995.

Dari elaborasi di atas dapat dipelajari bahwa collective action yang dapat dikembangkan dalam kerangka kerjasama dapat mengambil bentuk policy network, organization, election atau riot. Pembentukan "Organisasi" dalam kerjasama antar daerah adalah format ideal ketika kerjsama itu bercirikan koordinasi yang tinggi, dan adanya kesamaan interes diantara para aktor. Policy Network adalah format aksi kelompok yang paling ideal dalam kondisi koordinasi antar aktor tinggi, sekaligus juga interes yang berbeda dari para aktor. Sedangkan riot atau "kerusuhan" adalah collective action ketika diantara para aktor terikat dalam kordinasi yang longgar, namun memiliki kesamaan interes diantara mereka.

Layaknya tanaman, maka kerjasama juga harus di maintain dan dikelola agar tumbuh semakin membesar dan memberi banyak faedah. Dalam konteks otonomi daerah, menurut Ari Ruhyanto (2007) dalam Pratikno (2007), ada banyak sekali faktor yang bermain dalam pengembangan kerjasama antar daerah. Beberapa faktor itu adalah: Adanya fokus outward diantara para aktor yang bekerja sama; Adanya keinginan bersama antar daerah yang tergabung, Adanya refleksi antar daerah yang tergabung;Ada kesadaran diri akan arti penting kerjsama antar daerah, adanya kesadaran untuk belajar dan berbagi, akuntabilitas, transparansi dan kelembagaan yang jelas.

\section{Landasan Hukum}

Pengertian Kerjasama Daerah, menurut PP 50 Tahun 2007, Pasal 1, adalah kesepakatan antara gubernur dengan gubernur atau gubernur dengan bupati/wali kota atau antara bupati/wali kota dengan bupati/wali kota yang lain, dan atau gubernur, bupati/wali kota dengan pihak ketiga, yang dibuat secara tertulis serta menimbulkan hak dan kewajiban. Pihak ketiga sebagaimana dimaksud didalam kerjasama antar daerah itu adalah Departemen/Lembaga Pemerintah Non Departemen atau sebutan lain, perusahaan swasta yang berbadan hukum, Badan Usaha Milik Negara, Badan Usaha Milik Daerah, Koperasi, Yayasan, dan lembaga di dalam negeri lainnya yang berbadan hukum. Untuk melaksanakan kerjasama daerah, maka dapat dibentuk Badan Kerja, yaitu suatu forum untuk melaksanakan kerja sama yang keanggotaannya merupakan wakil yang ditunjuk dari daerah yang melakukan kerja sama.

Kerjasama Daerah yang dibentuk haruslah didasarkan pada prinsip-prinsip yang dapat mendorong manfaat dan efektivitas kerjasama itu. Bebebrapa prinsip yang diatur dalam PP 
50/2007 pada Pasal 2 adalah efisiensi,efektivitas,sinergi, saling menguntungkan,kesepakatan bersama,itikad baik, mengutamakan kepentingan nasional dan keutuhan wilayah Negara Kesatuan Republik Indonesia, persamaan kedudukan, transparansi, keadilan, kepastian hukum.

Dalam hal kerjasama yang dibentuk berimplikasi kepada pembebanan anggaran APBD dan/atau masyarakat) maka kerjasama itu harus mendapatkan persetujuan dari DPRD, Namun jika kerjasama tersebut dalam rangka meningkatkan efektivitas tugas pokok dan fungsi pemerintah Kab/Kota, maka persetujuan dewan tidak diperlukan (Pasal 9,10 PP 50/2007)

Melaksanakan PP 50/2007, Mendagri menerbitkan dua buah Peraturan Menteri Dalam Negeri (Permendagri) No 22 dan 23 Tahun 2009 yang mengatur tentang Pembinaan dan Pengawasan Kerjasama Daerah, dan Permendagri 23/2009 mengatur tentang Pentunjuk Teknis Kerjasama Daerah. Permendagri ini mengatur secara amat terperinci dan merupakan petunjuk teknis melaksanakan kerjasama antar daerah.

Beberapa bentuk kerjasama sebagaimana dimuat dalam lampiran 2 Permendagri 23/2009 yang meliputi Bentuk/Model Kerjasama Antar Daerah, Kerjasama Pemerintah Daerah dengan Departemen/LPND, serta Pemerintah Daerah dengan Badan Hukum Dalam Permendagri tersebut, bentuk /model kerja sama daerah dapat dilaksanakan sebagai berikut :

a. Bentuk/Model Kerja Sama Antar Daerah.

Meliputi:

1) Kerja Sama Pelayanan Bersama.

2) Kerja Sama Pelayanan Antar Daerah

3) Kerja Sama Pengembangan Sumberdaya Manusia

4) Kerja Sama Pelayanan dengan pembayaran Retribusi

5) Kerja Sama Perencanaan dan Pengurusan.

6) Kerja Sama Pembelian Penyediaan Pelayanan

7) Kerja Sama Pertukaran Layanan (imbal layan).

8) Kerja Sama Pemanfaatan Peralatan

9) Kerja Sama Kebijakan dan Pengaturan

b. Bentuk/Model Kerja Sama Pemerintah Daerah Dengan Departemen/LPND :

Obyek kerja sama daerah yang dapat ditawarkan kepada pemerintah adalah dalam rangka pengembangan sektor unggulan tertentu atau pengelolaan kawasan strategis yang menurut peraturan telah ditetapkan menjadi kewenangan daerah otonom.

Contoh kerja sama Pemerintah Derah dengan Departemen / LPND :

1) Kerja Sama Kebijakan dan Pengaturan,

2) Kerja Sama Pengembangan Sumberdaya Manusia dan Teknologi, .

3) Kerjasama Perencanaan dan Pengurusan,

c. Bentuk/Model Kerja Sama Pemerintah Daerah Dengan Badan Hukum.

Untuk menyelenggarakan urusan pemerintahan yang telah menjadi kewenangan otonom atau dapat berupa pelayanan publik, pemerintah daerah dapat bekerjasama dengan badan hukum. Pengertian Badan Hukum adalah perusahaan swasta , Badan Usaha Milik Negara, Badan Usaha Milik Daerah, koperasi, yayasan dan lembaga lain di dalam negeri lainnya yang berbadan hukum.

Kerjasama dengan Badan Hukum secara umum dapat berbentuk:

(a) Kontrak Pelayanan,

(b) Kontrak Bangun,

(c) Kontrak Rehabilitasi,

(d) Kontrak Patungan. 


\section{Perkembangan Kerjasama Daerah}

Otonomi daerah digulirkan dengan alasan utama memperbaiki kinerja pemerintah, dengan cara memperkuat kinerja Pemerintah Daerah. Harapannya jika kinerja pemerintahan daerah menguat, maka pelayanan publik juga akan membaik. Ujungnya kesejahteraan masyarakat meningkat, kemiskinan menurun, pengangguran juga akan menurun. Namun harapan dan tujuan otonomi daerah nampaknya masih bersifat "jauh panggang dari api"; artinya otonomi daerah ternyata belum memberi hasil substantif membaik.

Data BPS berikut memperkuat indikasi itu:

\section{Tabel 2:}

Tingkat Pertumbuhan Ekonomi, Tingkat Kemiskinan dan Tingkat Pengangguran Di Indonesia Tahun1996- 2011

\begin{tabular}{cccc}
\hline Tahun & $\begin{array}{c}\text { Tingkat Pertumbuhan } \\
\text { Ekonomi } \\
(\%)\end{array}$ & $\begin{array}{c}\text { Tingkat } \\
\text { Kemiskinan } \\
(\%)\end{array}$ & $\begin{array}{c}\text { Tingkat } \\
\text { Pengangguran } \\
(\%)\end{array}$ \\
\hline 1996 & 7,8 & 17,7 & 4,9 \\
1997 & 4,7 & $-*$ & 4,7 \\
1998 & $-13,1$ & 24,2 & 5,5 \\
1999 & 0,8 & 23,4 & 6,4 \\
2000 & 4,9 & 19.1 & 6,1 \\
2001 & 3,3 & 18.4 & 8,1 \\
2002 & 3,6 & 18.2 & 9,1 \\
2003 & 4,1 & 17.4 & 9,5 \\
2004 & 5,1 & 16.7 & 11,2 \\
2005 & 6,3 & 16,0 & 10,3 \\
2006 & 5,5 & 17.7 & 9,7 \\
2007 & 6,3 & 16,6 & 8,4 \\
2008 & 6,1 & 15,4 & 7,9 \\
2009 & 4,2 & 14,2 & 7,1 \\
2010 & 6,1 & 13,3 & 6,6 \\
2011 & 6,5 & 12,5 & \\
\hline
\end{tabular}

Dari indikator terpenting hasil pembangunan, yakni Tingkat pertumbuhan Ekonomi, Tingkat Kemiskinan dan Tingkat Pengangguran tahun-tahun setelah Otonomi Daerah (setelah 2007), ternyata tidak mengalami perubahan yang signifikan. Sehingga dapat diartikan otonomi daerah belum mampu meningkatkan tingkat pertumbuhan ekonomi, Mengurangi kemiskinan dan menurunkan tingkat pengangguran. Beberapa pengamat bahkan mengatakan bahwa otonomi daerah di Indonesia telah gagal mengemban misi utamanya. Beberapa penyebab kegagalan itu telah diidentifikasi beberapa peneliti. Diantaranya adalah Penelitian Institut Pertanian Bogor (2012), yang menyatakan kegagalan pemerintah dalam meningkatkan kesejahteraan setidaknya disebabkan oleh dua hal: Pertama, munculnya permasalahan sosial politik sebagai akibat dari diberlakukannya otonomi daerah. Dan yang Kedua, hampir setiap daerah menghadapi persoalan ekonomi berupa rendahnya skala ekonomi yang dimiliki oleh masing-masing daerah sehingga setiap daerah menjadi sangat sulit untuk mengembangkan kegiatan perekonomian daerahnya dalam rangka meningkatkan kesejahteraan masyarakat. Hal ini tidak terlepas dari keterbatasan keuangn daerah untuk membiayai kebutuhan pembangunan.

Menurut Brojonegoro, 2008; Proses desentralisasi di Indonesia baru pada tahap desentralisasi dari sisi pengeluaran pemerintah dan belum sampai pada tahap desentralisasi dari sisi penerimaan. Sehingga sebagian besar pemerintah daerah dalam membiayai pembangunannya yang tercermin dalam besaran Anggaran Pendapatan dan Belanja Daerah (APBD) lebih mengandalkan subsidi dari pemerintah pusat melalui dana perimbangan yang ditransfer dari pusat ke daerah dalam beberapa skema (Brodjonegoro, 2008).

Persoalan lain yang muncul akibat otonomi daerah adalah munculnya "Batas Administratif" yang membatasi cara pandang yang lebih luas dalam memandang dan menyelesaikan sebuah persoalan pembangunan. Kasus Pemberantasan Penyakit Malaria oleh Kab. Kulon Progo terpaksa berhenti di wilayah perbatasan dengan Sleman dan Purworejo; 
padahal berhentinya upaya pada batas administratif dapat menggagalkan upaya pemberantasan wabah malaria secara keseluruhan. Demikian pula dalam banyak persoalan pembangunan yang lain. Ironi yang muncul adalah bahwa perosoalan pembangunan berkembang dalam satuan "kawasan/region" sementara kebijakan publik untuk mengatasinya terkotak dalam wilayah administratif. Otonomi daerah tidak jarang juga menjebak sebuah daerah ada dalam "kemampuan sumberdaya pembangunan" yang relatif kecil dibanding persoaalan besar yang dihadapi.

Oleh karena itu, Jeremias T Keban melihat Kerjasama antar Daerah menjadi salah satu solusi untuk mengatasi persoalan pembangunan di Daerah. Dengan kerjasama antar daerah maka sebuah persoalan dapat diselesaikan secara lebih holistik, dan skala kekuatan pendanaan juga akan semakin meningkat. Dan dengan itu, persoalan-persoalan pembangunan di kawasan perbatasan dapat diatasi dengan lebih efektif. (Jeremias T Keban:2010). Di lapangan, ternyata apa yang difikirkan para ahli tentang "the power of partnership" ternyata disambut dengan antusias. Hal ini terlihat dari telah tumbuh dan berkembangnya berbagai bentuk kerjasama daerah yang telah ada. Pratikno (2007), dan Abdurrachman (2009) berhasil mengidentifikasi berbagai jenis kerjasama itu sebagai berikut:

Tabel 3:

Nama Lembaga dan Pola Kerjasama Antar Daerah di Indonesia

\begin{tabular}{|c|c|c|c|}
\hline No & $\begin{array}{c}\text { Format } \\
\text { kelembagaa } \\
\mathrm{n}\end{array}$ & Nama Lembaga & Lingkup Wilayah dan Keanggotaan Daerah \\
\hline \multirow[t]{6}{*}{1} & $\begin{array}{l}\text { Asosiasi } \\
\text { Antar } \\
\text { Daerah }\end{array}$ & $\begin{array}{l}\text { 1. APKASI (Asosiasi Pemerintah } \\
\text { Kabupaten Seluruh Indonesia }\end{array}$ & Seluruh Pemerintah Kabupaten di Indonesia \\
\hline & & $\begin{array}{l}\text { 2. APEKSI (Asosiasi Pemerintah } \\
\text { Kota Seluruh Indonesia) }\end{array}$ & Seluruh Pemerintah Kota di Indonesia \\
\hline & & $\begin{array}{l}\text { 3. ADKASI (Asosiasi DPRD } \\
\text { Kabupaten Seluruh indonesia }\end{array}$ & Seluruh DPRD se Indonesia \\
\hline & & $\begin{array}{l}\text { 4. ADEKSI (Asosiasi DPRD Kota } \\
\text { Seluruh Indonesia) }\end{array}$ & Seluruh DPRD Kota di Indonesia \\
\hline & & $\begin{array}{l}\text { 5. APPSI (Asosiasi Pemerintah } \\
\text { Propinsi Seluruh Indonesia) }\end{array}$ & Seluruh Pemerintah Propinsi di Indonesia \\
\hline & & $\begin{array}{l}\text { 6. ADEPSI (Asosiasi DPRD } \\
\text { Propinsi Seluruh Indonesia } \\
\end{array}$ & Seluruh DPRD Propinsi di Indonesia \\
\hline \multirow[t]{9}{*}{2.} & $\begin{array}{l}\text { Kerjasama } \\
\text { Regional }\end{array}$ & 1. BKSAD Jabodetabek & $\begin{array}{l}\text { Propinsi DKI Jakarta, Jabar (Kabupaten dan } \\
\text { Kota Bogor, Kabupaten dan Kota Bekasi, Kota } \\
\text { Depok), Prop. Banten (Kab \& Kota Tengerang) }\end{array}$ \\
\hline & & 2. BARLINGMASCAKEB & $\begin{array}{l}\text { Prop. Jawa Tengah, meliputi Kabupaten } \\
\text { Banjarnegara, Perbalingga, Banyumas, Cilacap } \\
\text { dan Kota Kebumen }\end{array}$ \\
\hline & & 3. KARTAMANTUL & Kota Yogyakarta, Kab. Sleman dan Kab. Bantul \\
\hline & & 4. SUBOSUKAWONOSRATEN & $\begin{array}{l}\text { Kota Surakarta, Kabupaten Boyolali, Kab. } \\
\text { Sukoharjo, , Kab. Wonogiri, Kab. Sragen dan } \\
\text { Kab. Klaten }\end{array}$ \\
\hline & & 5. SAMPAN & $\begin{array}{l}\text { Kab: Brebes, Kota dan Kab. Tegal, Kab. } \\
\text { Pemalang dan Kab. Batang }\end{array}$ \\
\hline & & 6. JAVA PROMO & $\begin{array}{l}\text { DIY: Kota Yogyakarta, Kab Sleman, } \\
\text { Kulonprogo, Bantul dan Gunungkidul, Prop. } \\
\text { Jateng: Kab. Klaten, Boyolali, Kab dan Kota } \\
\text { Magelang, Kab. Temanggung, Wonosobo, } \\
\text { Purworejo dan Kab. Kebumen }\end{array}$ \\
\hline & & 7. GERBANGKERTOSUSILA & $\begin{array}{l}\text { Kabupaten/Kota: Gresik, Bangkalan, Mojokerto, } \\
\text { Surabaya. Sidoarjo dan Lamongan. }\end{array}$ \\
\hline & & 8. LAKE TOBA & $\begin{array}{lcc}\text { Kab/Kota Samosir, } & \text { Tapanuli } & \text { Utara, } \\
\text { Simalungun, Humbang Hasundutan } & \\
\end{array}$ \\
\hline & & 9. JONJOK BATUR & Kab/Kota Lombok Barat, Lombok Tengah dan \\
\hline
\end{tabular}




\begin{tabular}{|c|c|c|c|}
\hline & & & Lombok Timur \\
\hline & & 10. PAWONSARI & $\begin{array}{l}\text { JATIM: Kab/Kota Pacitan, Wonogiri dan DIY: } \\
\text { Gunungkidul (Wonosari) }\end{array}$ \\
\hline & & 11. KEDUNGSEPUR & $\begin{array}{l}\text { Kendal, Demak, Ungaran (Kab. Semarang), } \\
\text { Kota Semarang dan Purwodadi }\end{array}$ \\
\hline & & 12. JANHIANBONG & $\begin{array}{l}\text { Kepahingan, Lebong, Rejang Lebong (Prop } \\
\text { Bengkulu) }\end{array}$ \\
\hline & & 13. KAUKUS SETARA KUAT & $\begin{array}{l}\text { Kab/Kota: Kaur, Bengkulu Selatan, Bengkulu } \\
\text { Utara, (Prop Bengkulu); OKU (Sumsel), } \\
\text { Lampung Barat (Prop Lampung) }\end{array}$ \\
\hline & & $\begin{array}{l}\text { 14. ANDALAN KAWASAN } \\
\text { SELATAN SULSEL }\end{array}$ & $\begin{array}{l}\text { Kab/Kota: Bantaeng, Bulukumba, Jeneponto, } \\
\text { Selayar dan Sinjai }\end{array}$ \\
\hline & & 15. WANUA MAPPATUO & $\begin{array}{l}\text { SULSEL: Luwu, Luwu Utara, Luwu Timur, } \\
\text { Tana Toraja, Toraja Utara dan Kota Palopo }\end{array}$ \\
\hline & & 16. PULAU SUMBAWA & $\begin{array}{l}\text { Kab/Kota: Bima, Dompu, Sumbawa, Sumbawa } \\
\text { Barat. }\end{array}$ \\
\hline & & $\begin{array}{l}\text { 17. KAWASAN TERPADU } \\
\text { TELUK TOMINI }\end{array}$ & $\begin{array}{l}\text { PROPSULTENG: Kab. Banggai Kepulauan, } \\
\text { Banggai, Tojo Una Una, Poso dan Parigi } \\
\text { Moutong } \\
\text { PROP GORONTALO: Phuwato, Boalemo, } \\
\text { Bone Bolango, Kab\&Kota Gorontalo } \\
\text { PROP. SULUT: Bolaang Mongondow, dan } \\
\text { Minahasa Tenggara }\end{array}$ \\
\hline & & $\begin{array}{l}\text { 18. KAWSAN } \\
\text { TELUK BONE }\end{array}$ & $\begin{array}{l}\text { SULSEL: Kab. Selayar, Bulukumba, Sinjai, } \\
\text { Bone, Wajo, Luwu, Luwu Utara, Luwu Timur } \\
\text { dan Kota Palopo } \\
\text { SULAWESI UTARA: Kolaka Utara, Kolaka, } \\
\text { Bombana, Buton, Muna dan Kota Rau-Rau }\end{array}$ \\
\hline & & $\begin{array}{l}\text { 19. KAWASAN PERBATASAN } \\
\text { PROPINSI KALIMANTAN } \\
\text { BARAT }\end{array}$ & $\begin{array}{l}\text { KALBAR: Sintang, Kapuas Hulu, Sanggau, } \\
\text { Bangkayang }\end{array}$ \\
\hline & & $\begin{array}{l}\text { 20. KAWASAN PERBATASAN } \\
\text { NUSA TENGGARA TIMUR }\end{array}$ & $\begin{array}{l}\text { NTT: Timor Tengah Utara, Timor Tengah } \\
\text { Selatan, Belu dan Rotendau }\end{array}$ \\
\hline & & 21. KAWASAN TELUK PAPUA & $\begin{array}{l}\text { PAPUA BARAT: Fak-Fak, Sorong Selatan, } \\
\text { Kaimana, Teluk Bintuni dan Teluk Wondana }\end{array}$ \\
\hline
\end{tabular}

Sumber: Pratikno, (2007) Abdurahman, (2009)

Setelah pendataan Pratikno (2007) dan Abdurahman (2009) itu, tentu banyak format kerjasama yang timbul Tenggelam. Di Lokasi Survai misalnya telah muncul kaukus KUNCI BERSAMA (Kuningan, Cilacap, Brebes dan Tasik Malaya), serta JRATUNSELUNA (Jragung Tuntang, Serang, Lusi dan Juwana) yaitu kaukus daerah berdasarkan kawasan sungai Jeragung, Tuntang, Serang, Lusi dan Juwana.

\section{Potret Pelaksanaan Kerjasama Antar Daerah di Cilacap, Wonosobo, DIY dan Semarang}

Berdasarkan pengalaman penyelenggaraan Kerja Sama Antar Daerah di 4 lokasi survai, dapat dielaborasi beberapa aspek penting dalam pengembangan sistem kelembagaan kerjasama antar daerah sebagaimana akan dipaparkan bada bagian berikut ini. Namun karena besarnya muatan yang akan dielaborasi, maka agak sulit untuk membandingkan "apple to apple" ke empat pengalaman itu. Oleh karena itu elaborasi akan disajikan secara parsial, satu demi satu dalam aspek yang sama.

\section{LOKASI KABUPATEN CILACAP}

Kabupaten Cilacap memiliki sejumlah alasan yang kuat untuk mengembangkan kerjasama antar daerah. Secara geografis Cilacap ada pada lokasi yang "terpencil" dari arus 
perkembangan ekonomi di Jawa Tengah. Sebagai Kota Pelabuhan yang "besar" pada masanya, Cilacap kini hanya tinggal nama, karena pergeseran trend angkutan barang yang banyak meninggalkan transportasi laut. Sebagai Kabupaten yang potensinya besar, Pemerintah dan Masyarakat Kabupaten Cilacap kini merasa kurang diperhatikan dan "jauh" dari Semarang (Ibu Kota Propinsi). Secara kultural, Cilacap justru merasa dekat dengan kabupaten/kota Kuningan, Kebumen, Banyumas, Brebes dan Banjar. Kedekatan kultur ini juga mendorong Cilacap merasa lebih "nyaman" bekerjasama dengan daerah-daerah itu. Dari sisi potensi daerah Cilacap juga memiliki karakterisitik yang hampir sama dengan Banjarnegara, Purbalingga, Banyumas dan Kebumen. Jadilah Kabupaten ini memiliki riwayat kerjasama yang sudah cukup lama. Namun demikian karena batasan regulasi, Kerjasama yang mereka bina tidak kunjung menjadi bentuk kerjasama yang efektif, dalam pengertian dapat membuat perencanaan, pendanaan dan eksekusi. Kerjasama-kerjasama yang dirintis baru berhenti pada tataran koordinatif yang tidak terlalu kuat. Berikut ini potret kerjasama yang telah dilaksanakan:

Tabel 4:

Kerjasama Daerah Kab. Cilacap

\begin{tabular}{|c|c|c|}
\hline 1. & Kasus Yang diamati & $\begin{array}{l}\text { KUNCIBERSAMA (Kuningan, Cirebon, Ciamis, Cilacap, Kab } \\
\text { Banjar, Kota Banjar, Brebes, dan Majalengka ) } \\
\text { BARLINGMASCAKEB (Banjarnegara, Purbalingga, Banyumas, } \\
\text { Cilacap, dan Kebumen) }\end{array}$ \\
\hline 2. & Bentuk Kelembagaan & $\begin{array}{l}\text { Koordinasi antar Daerah; dan hasilnya ditindaklanjuti dalam bentuk } \\
\text { kerjasama sektoral. } \\
\text { Barlingmascakeb: membentuk sebuah "Tim Manajemen" (Forum } \\
\begin{array}{l}\text { Regional, Dewan Eksekutif } \\
\text { menindaklanjuti kerjasama itu }\end{array}\end{array}$ \\
\hline 3 & Dasar Hukum & $\begin{array}{l}\text { Barlingmascakeb: SKB } 5 \text { Bupati } \\
\text { Kuncibersama: Kuningan Summit - Deklarasi Antar Daerah }\end{array}$ \\
\hline 4 & Visi - Misi, Tupoksi & $\begin{array}{l}\text { Balingmascakeb: } \\
\text { (1) Mewujudkan sinergi dalam pelaksanaan pembangunan antar } \\
\text { daerah untuk meningkatkan efisiensi dan efektivitas } \\
\text { pemanfaatan sumberdaya pembangunan; } \\
\text { (2) Sinkronisasi dalam penyusunan peraturan daerah untuk } \\
\text { mengurangi hambatan birokrasi dalam kegiatan ekonomi dan } \\
\text { investasi; } \\
\text { (3) Menghindari persaingan yang tidak sehat antar daerah; } \\
\text { (4) Memperkuat posisi tawar dan meningkatkan daya saing } \\
\text { daerah agar mampu mengakses pasar nasional dan } \\
\text { internasional dalam era globalisasi ekonomi; } \\
\text { (5) Meningkatkan efisiensi dan efektivitas promosi daerah; dan } \\
\text { (6) Membangun kemitraan antar daerah dan antara pemerintah } \\
\text { kabupaten dengan provinsi. } \\
\text { KUNCIBERSAMA: } \\
\text { 1. Penguatan Ekonomi Daerah Perbatasan Jabar-Jateng } \\
\text { 2. Diduga menjadi "cikalbakal" pemekaran daerah menuju } \\
\text { Propinsi Baru. }\end{array}$ \\
\hline 5. & Stakeholder Utama & $\begin{array}{l}\text { - } \text { Kepala Daerah (sebagai pembuka jalan dan pengambil keputusan } \\
\text { - } \quad \text { Bappeda untuk melakukan kordinasi program } \\
\text { - } \quad \text { Instansi Teknis untuk tindak lanjut kegiatan teknis } \\
\text { - } \quad \text { Manajemen Regional (belakangan mati karena tiadanya skema } \\
\text { pendanaan yang jelas) }\end{array}$ \\
\hline 6. & Cakupan Layanan & $\begin{array}{ll}- & \text { Kordinasi program } \\
\text { - } & \text { Kordinasi kegiatan } \\
\text { - } & \text { Penyelesaian konflik perbatasan } \\
\text { - } & \text { Pameran/promosi bersama } \\
\end{array}$ \\
\hline 7. & Skema Pendanaan & $\begin{array}{l}\text { - } \quad \text { Iuran Daerah; bersifat tidak rutin, dilakukan per kegiatan } \\
\text { - } \quad \text { ini juga bermasalah karena skema yang paling dimungkinkan untuk }\end{array}$ \\
\hline
\end{tabular}

10 Jurnal Maksipreneur, Vol. II, No. 2, Juni 2013 


\begin{tabular}{|c|c|c|}
\hline & & lembaga semacam ini adalah hibah sosial \\
\hline 8. & Kinerja & $\begin{array}{l}\text { - kordinasi antar daerah } \\
\text { - } \quad \text { kesepahaman anatar daerah } \\
\text { - deklarasi bersama }\end{array}$ \\
\hline \multirow[t]{5}{*}{9} & SWOT & \\
\hline & Strength & $\begin{array}{l}\text { - Munculnya kesadaran antar daerah tentang pentingnya kerjasama } \\
\text { antar daerah dalam mengatasi problem infrastruktur } \\
\text { - Sudah muncul (dalam tahap elementer) kelembagaan kerjasama } \\
\text { yang bisa dikembangkan } \\
\text { - Kerjasama teknis sudah sering dilakukan dalam skema dinas } \\
\text { teknis-dinas teknis }\end{array}$ \\
\hline & Weaknesses & $\begin{array}{l}\text { - } \begin{array}{l}\text { Problem regulasi yang membatasi pendanaan kerjasama antar } \\
\text { daerah }\end{array} \\
\text { - } \text { Kelembagaan yang kuat menjadi susah dibentuk } \\
\text { Seringkali karena potensi yang hampir sama, justru muncul konflik } \\
\text { antar daerah } \\
\text { Belum ada kepemimpinan daerah yang bisa mentransformasikan } \\
\text { komitmen bersama menjadi kerjsama teknis yang efektif. } \\
\text { KSAD sering menjadi "alat politik" untuk menekan Pemerintah } \\
\text { Propinsi/Pusat }\end{array}$ \\
\hline & Oportunities & $\begin{array}{ll}\text { - } & \text { Dana Dekonsentrasi } \\
\text { - } & \text { Dorongan Pemerintah Pusat untuk kerjasama antar daerah } \\
\text { keberadaan Pemerintah Propinsi yang bisa menjadi "payung" }\end{array}$ \\
\hline & Threaths & 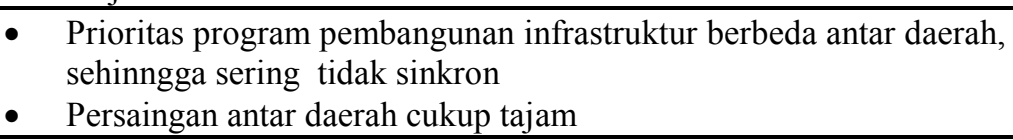 \\
\hline 10 & Keberlanjutan Layanan & Mati suri \\
\hline
\end{tabular}

\section{LOKASI WONOSOBO}

Kabupaten Wonosobo ada pada posisi geogrfis di tengah-tengah Wilayah Propinsi Jawa Tengah. Sejumlah potensi dan kendala dihadapi oleh Kab. Wonosobo dan daerah-daerah sekitarnya seperti Pemalang, Banjarnegara, Temanggung dan Kebumen yang cenderung berkarakteristik dataran tinggi dan pegunungan. Namun kawasan ini entah mengapa tidak memiliki riwayat kerjasama kawasan. Diduga karena para pimpinan daerah ini belum menganggap kerjasama antar daerah menjadi 'kunci' mengatasi persoalan-persoalan daerah yang tidak bisa atau tidak optimal diatasi sendiri.

Tabel 6:

Kerjasama Daerah Kab. Wonosobo

\begin{tabular}{|l|l|lll|}
\hline $\mathbf{1 .}$ & Kasus Yang diamati & Kerjasama Teknis & \\
\hline $\mathbf{2 .}$ & Bentuk Kelembagaan & Belum ada Kerjasama yang Spesifik & \\
\hline $\mathbf{3 .}$ & Visi - Misi, Tupoksi & Kerjasama mengatasi permasalahan perbatasan & \\
\hline $\mathbf{4 .}$ & Stakeholder Utama & Unit Kerjasama, Pemda. & \\
\hline $\mathbf{5 .}$ & Cakupan Layanan & Kasuistik, fokus pada persoalan-persoalan perbatasan & \\
\hline $\mathbf{6 .}$ & Skema Pendanaan & $\begin{array}{l}\text { APBD melalui Dinas Teknis, dalam bentuk program } \\
\text { pembangunan }\end{array}$ & & \\
\hline $\mathbf{7 .}$ & Kinerja & Minimal & & \\
\hline $\mathbf{8}$ & SWOT & \multicolumn{4}{l}{ Sudah mulai diidentifikasi persoalan=persoalan yang } \\
& Strength & &
\end{tabular}




\begin{tabular}{|l|l|l|}
\hline & Weaknesses & $\begin{array}{l}\text { - Kelembagaan belum terbentuk } \\
\text { - Persoalan perbatasan diselesaikan kasuistik dalam bentuk } \\
\text { kesepakatan } \\
\text { - Alokasi pendanaan minim } \\
\text { - Belum ada kesepakatan fokus persoalan yang akan } \\
\text { dikerjasamakan }\end{array}$ \\
\hline & Oportunities & $\begin{array}{l}\text { Perkembangan kawasan cukup pesat sehingga menuntut kerjasama } \\
\text { antar daerah }\end{array}$ \\
\hline $\mathbf{9}$ & Threaths & $\begin{array}{l}\text { Persaingan antar kawasan } \\
\text { Regulasi belum mendukung }\end{array}$ \\
\hline $\mathbf{1 0}$ & Isu Strategis & $\begin{array}{l}\text { Tidak jelas } \\
\text { - Diperlukan komitmen dan prakarsa pimpinan daerah } \\
\text { - Kerjasama dimulai dengan fokus pada persoalan-persoalan yang } \\
\text { penting untuk dikerjasamakan } \\
\text { - Perlu kajian intensif untuk mengkaji potensi kerjasama antar } \\
\text { daerah di kawasan ini }\end{array}$ \\
\hline
\end{tabular}

\section{LOKASI KOTA YOGYAKARTA}

Dari sisi potensi daerah, Kota Yogyakarta yang luasannya kecil tidaklah memiliki sumberdaya alam yang memadai. Yogyakarta tidak lagi memiiki lahan pertanian, hasil tambang dan lain-lain sumberdaya alam. Kota ini banyak bergantung kepada daerah-daerah sekitarnya Sleman, Bantul dan Guningkidul; atau bahkan yang lebih luas dengan propinsi Jawa Tengah (Joglosemar). Namun dari sisi Sumberdaya Manusia Kota ini melimpah dengan potensi yang kuat. Sejumlah Perguruan Tinggi besar ada di sini, NGO Nasional dan Internasional juga menempatkan kota ini sebagai kota yang penting. Pimpinan Daerah (Walikota dan Gubernur) juga sudah sangat sadar dengan persoalan - persoalan ini. Sejumlah faktor inilah yang mungkin mendorong tumbuh dan kuatnya jalinan kerjasama antar daerah Kota ini dengan kawasan di sekitarnya. Kartamantul sebuah lembaga yang oleh beberapa peneliti dikelompokkan sebagai kuasi otonom telah cukup lama berdiri dan eksis mengatasi persoalan persoalan besar di Kota ini. Pengelolaan sampah, transportasi kota, asinering/pengelolaan limbah, dan air bersih adalah persoalan-pereoalan besar yang bisa diatasi sebagian karena peran lembaga kerjasama ini.

Tabel 7:

Kerjasama Daerah Yogyakarta

\begin{tabular}{|c|c|c|}
\hline 1. & $\begin{array}{ll}\text { Kasus } & \text { Yang } \\
\text { diamati } & \end{array}$ & Kartamantul (Yogyakarta, Sleman,Bantul) \\
\hline 2. & $\begin{array}{l}\text { Bentuk } \\
\text { Kelembagaan }\end{array}$ & $\begin{array}{l}\text { Lembaga Quasy Otonom } \\
\text { Sekretariat Bersama: Kerjasama Fasilitasi, Perencanaan dan Mediasi } \\
\text { Dasar: SKB tiga pimpinan daerah yang tertuang dalam Surat } \\
\text { keputusan bersama Bupati Bantul, Bupati Sleman dan Walikota } \\
\text { Yogyakarta No } 18 \text { tahun } 2001 \text { Tentang Pembentukan Sekertariat } \\
\text { Bersama Kartamantul }\end{array}$ \\
\hline 3. & $\begin{array}{l}\text { Visi }- \\
\text { Tupoksi }\end{array}$ & $\begin{array}{l}\text { JSK di bentuk sebagai forum fasilitasi, perencana dan mediasi untuk } \\
\text { memudahkan koordinasi antar tiga daerah dalam menentukan } \\
\text { penyediaan pelayan yang terpilih. yaitu: pengelolaan sampah, } \\
\text { pengelolaan limbah, penyediaan air bersih, saluran pembuangan, } \\
\text { jalan dan transportasi. } \\
\text { Misi Sekber Kartamantul: } \\
\text { 1) Melakukan negosiasi untuk mendapatkan hasil yang adil, } \\
\text { 2) Melakukan mediasi penyelesaian permasalahan, } \\
\text { 3) Melakukan koordinasi manajemen dan implementasi, } \\
\text { 4) Melakukan fasilitasi proses pengambilan keputusan, } \\
\text { 5) Membangun jaringan kerja yang kuat, }\end{array}$ \\
\hline
\end{tabular}




\begin{tabular}{|c|c|c|}
\hline & & 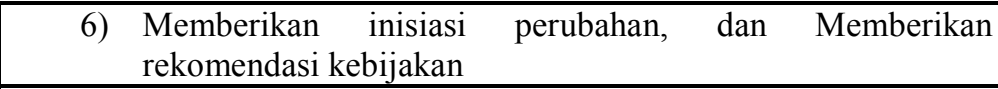 \\
\hline 4. & Stakeholder Utama & Sekretariat Bersama, Pemerintah Kab/Kota, NGO \\
\hline 5. & Cakupan Layanan & Kawasan Yogyakarta (Kota), Sleman, Bantul \\
\hline 6. & Skema Pendanaan & $\begin{array}{l}\text { Iuran } 3 \text { Pemkab/Kota; } \\
\text { Tidak ada sumber pendanaan sendiri }\end{array}$ \\
\hline 7. & Kinerja & $\begin{array}{l}\text { Cukup baik/ efektif, terutama untuk bidang-bidang yang masalahnya } \\
\text { sudah dirasakan dan menjadi prioritas oleh ketiiga daerah (sampah, } \\
\text { air bersih, pengelolaan limbah }\end{array}$ \\
\hline \multirow[t]{5}{*}{8} & SWOT & \\
\hline & Strength & $\begin{array}{l}\text { - Komitmen dan kepentingan bersama yang mengikat Kartamantul } \\
\text { - NGO (GTZ) dan Kalangan Intelektual yang mendukung } \\
\text { Kartamantul } \\
\text { - Bentuk Badan Hukum memungkinkan Ia melakukan fund rising } \\
\text { lebih leluasa }\end{array}$ \\
\hline & Weaknesses & $\begin{array}{l}\text { - Tidak ada sumber pendanaan sendiri sehingga kinerjanya } \\
\text { tergantung alokasi iuran } 3 \mathrm{kab} / \mathrm{kota} \\
\text { - Kemandirian terbatas } \\
\text { - Tergantung pada iuran anggota } \\
\text { - Program tergantung prioritas dan dana yang disediakan oleh } \\
\text { masing-2 kab/Kota }\end{array}$ \\
\hline & Oportunities & $\begin{array}{l}\text { - Dukungan berbagai kalangan NGO, Negara Sahabat, Perguruan } \\
\text { Tinggi } \\
\text { - Pengalaman kerjasama antar } 3 \text { daerah } \\
\text { - Insentif untuk penyelenggaraan kerjasama antar daerah } \\
\end{array}$ \\
\hline & Threaths & $\begin{array}{ll}\text { - } & \text { Aglomerasi yang semakin pesat } \\
\text { - } & \text { Kesinambungan program sebagai akibat suksesi kepemimpinan }\end{array}$ \\
\hline 9 & $\begin{array}{l}\text { Keberlanjutan } \\
\text { Layanan }\end{array}$ & Cukup bagus/tinggi \\
\hline 10 & Isu Strategis & $\begin{array}{l}\text { - Pengaturan kerjasama perlu dirumuskan lebih rinnci agar tidak } \\
\text { menimbulkan kemacetan kerjasama di lapanngan. Misal masalah } \\
\text { tarif dan budget sharing } \\
\text { - Funngsi Kartamantul perlu di perluas dari sekedar kordinasi, tapi } \\
\text { juga perencanaan mandiri dan pengawasan kerjasama antar } \\
\text { daerah } \\
\text { - Sumber pendanaan yang lebih otonom / diatur melalui perda }\end{array}$ \\
\hline
\end{tabular}

\section{LOKASI KOTA SEMARANG}

Kerjasama Kota Semarang memiliki riwayat unik sekaligus penuh tandatanya. Kota ini memiliki posisi istimewa, karena sekaligus menjadi Ibukota Jawa Tengah. Oleh karena itu Semarang sesungguhnya menikmati limpahan perhatian dari Propinsi dan Pemerintah Pusat dalam mengembangkan kerjasama Semarang dengan kawasan sekitarnya. Tidak Kurang Gubernur Mardiyanto sudah merintis berdirinya Kedung Sepur di pertengahan tahun 90-an. Pemerintah Pusat juga menetapkan kawasan ini menjadi Kawasan Strategis Nasional. Sejumlah persoalan Kota Semarang juga sudah tidak lagi dapat diatasi sendiri, seperti Transportasi kota, pengelolaan sampah, kebutuhan pangan dan air bersih.

Namun dalam perkembangannya Kedungsepur tidak kunjung bertransformasi menjadi Kerjasama antar daerah yang kuat. Kedungsepur berhenti pada sekedar menjadi sebuah "kaukus" berbasis wilayah. Embrio kerjasama antar daerah ini seperti tidak memiliki progres perkembangan yang menggembirakan. Komitmen Pemerintah Kota nampaknya juga tidak cukup menggembirakan; alokasi subsidi terhadap kerjasama ini amat jauh dibanding alokasi subsidi kota ini terhadap bidang lain, seperti olahraga.

\section{Tabel 8:}


Kerjasama Semarang

\begin{tabular}{lll} 
1. Kasus Yang diamati & $\begin{array}{l}\text { KEDUNGSEPR (Kendal, Demak, Ungaran/Kab. Semarang, Semarang, } \\
\text { Purwodadi dan Kota Salatiga. })\end{array}$ \\
\hline 2. Bentuk Kelembagaan & $\begin{array}{l}\text { Kaukus berbasis wilayah yang dinisiasi oleh Gubernur (1998) } \\
\text { Belum ditindaklanjuti menjadi kerjasama teknis yang efektif. }\end{array}$ \\
3. Visi-Misi, Tupoksi & $\begin{array}{l}\text { kemitraan di bidang tata ruang, pelestarian, dan pemanfaatan sumber daya } \\
\text { alam serta lingkungan hidup, industri dan perdagangan, pembangunan sarana } \\
\text { dan prasarana, perhubungan dan pariwisata, kebersihan dan kesehatan, } \\
\text { pertanian dan pengairan, pendidikan dan kebudayaan, kependudukan, } \\
\text { ketenagakerjaan, masalah sosial, serta keamanan dan ketertiban. }\end{array}$
\end{tabular}

Gubernur, Bupati/walikota, Badan Koordinasi

5. Cakupan Layanan Kabupaten/Kota (Bakorlin)

6. Skema Pendanaan Wilayah Kedungsepur

Tidak jelas

Belum ada alokasi daerah untuk pendanaan Kedungsepur

Pendanaan masih ditanggung oleh Pemprof

\section{Kinerja \\ 8 SWOT \\ Strength}

Weaknesses

Oportunities

Threaths

9 Keberlanjutan

Layanan

10 Isu Strategis
- Layanan Transportasi BRT Kedungsepur

- Layanan air bersih

- Belum ada kerjasama yang efektif yang dihasilkan oleh kaukus ini

- Ada inisiatif yang kuat dari Gubernur

- Dukungan Pemerintah Pusat untuk mengembangkan Kawasan Strategis Nasional Kedungsepur

- belum terumuskannya visi bersama, komitmen bersama dan pemahaman masing-masing kepala daerah tentang urgensi kerjasama

- Belum ada komitmen kepala daerah Kedungsepur untuk menindaklanjuti menjadi kerjasama antar daerah

- Daerah belum menempatkan Kerjasama sebagai instrumen strategis untuk mendorong proses pembangunan

- Berbagai persoalan besar yang tidak dapat diselesaikan sendiri: Transportasi, air bersih, sampah, dan sanitasi

- Rencana Tata Ruang Kawasan Strategis Nasional (KSN) Kedungsepur untuk menjadi Kawasan Strategis Nasional

- Konflik /sengketa antar daerah

- Persaingan antar daerah

Tidak jelas

1. Kerjasama Antar Daerah di Kedungsepur belum dijadikan instrumen urama dalam pembangunan daerah dan pembangunan regional. Hal itu karena belum tersepakatinya "Visi Bersama" yang saling menguntungkan diantara anggota Kaukus Kedungsepur.

2. Berkaitan dengan itu, komitmen dan dukungan Pemerintah Kab/Kota terhadap Kerjasama Kedungsepur baik secara materiil dan moril masih amat rendah.

3. belum mampu mengidentifikasi issu-issu yang harus dikerjasamakan, sehingga merasa belum perlu memanfaatkan forum kerjsama secara lebih efektif.

4. Kerjasama antar daerah yang lebih efektif justru yang bersifat sektoral, temporer, dan fokus pada persoalan spesifik.

Dari elaborasi atas kerjasama yang dilaksanakan di ke empat daerah di atas dapat diidentifikasi beberapa issu strategis, yang berguna untuk menjadi bahan evaluasi bagi pelaksanaan kerjasama antar daerah ke depan.

\section{Issu Strategis:}

1. Kerjasama antar daerah harus dilandasi adanya suatu rumusan kebutuhan bersama diantara para anggota. 
Kerjasama dianggap sebagai kebutuhan bersama apabila masing-masing pemerintah daerah tidak mampu menyelesaikan permasalahan pembangunan yang dihadapainya seperti pengentasan kemiskinan, efisiensi pelayanan publik, konflik antar penduduk, dan lain-lainnya, kalau mereka tidak bekerjasama.

Oleh karena itu, identifikasi dan rumusan untuk menemukan kesamaan isu dan permasalahan pembangunan diantara anggota menjadi hal yang sangat penting untuk dilakukan.

2. Adanya komitmen bersama dari masing-masing pemerintah daerah dalam menangani isu-isu yang telah disepakati, dan lebih mendahulukan kepentingan bersama dibanding kepentingan masing-masing daerah.

3. Adanya prinsip saling menguntungkan bagi semua fihak untuk meandasi bekerjasama.

Prinsip saling meguntungkan menggambarkan bahwa dalam bekerjasama setiap anggota harus dapat menarik manfaat dari adanya kerjasama tersebut. Namun demikian, tidak berarti bahwa setiap daerah harus mendapatkan bentuk keuntungan yang seragam.

4. Adanya dukungan dari pemerintah

Dukungan baik dari Pemerintah Pusat maupun Provinsi terhadap kerjasama antar daerah yang dilakukan oleh pemerintah kabupaten/kota amat diperlukan. Dukungan dapat berupa bantuan pendanaan,pelimpahan kewenangan maupun penyediaan aturan perundangan sebagai dasar hukum untuk melakukan kerjasama antar daerah.

5. Kerjasama yang berjalan sering kandas, karena kurangnya dukungan dari pemerintah pusat yaitu tidak adanya koordinasi, komunikasi dan kerjasama lintas sektoral di tingkat pusat,

6. Minimnya komitmen pimpinan daerah atau karena tingginya ego daerah,

7. Terbatasnya kapasitas personal pengelola kerjasama antar daerah yang berasal dari PNS karena terkendala dengan tupoksi utamanya,

8. Partisipasi masyarakat yang rendah,

\section{DAFTAR PUSTAKA}

Brodjonegoro, 2009, Fiscal Desentralization and its Impact in Regional Economi Development and Fiscal Sustainability

Carisson;Lars.,1995PolicyMaking,CollectiveAction,andTheGovernabilityof

Society.;PaperdipresentasikandalamTheMiniConferenceonPolitical Order and Development

Gaffar; Karim Abdul (ed).,2003., Kompleksitas Pelaksanaan Otonomi Daerah di Indonesia”, JIP - UGM Yogyakarta

Henry, N. 1995. Public Administration and Public Affairs. Sixth Edition. Englewood Cliffs, N.J. : Prentice - Hall.

Keban, Jeremias,T., Kerjasama Antar Pemerintah Daerah dalam Era Otonomi: Isu Strategis, Bentuk, Prinsip, 2009, Ilmu Administrasi Negara, Fisipol, Yogyakarta

Kuswanto SA.,2006, Antara Sentralisasi dan Desentralisasi Pengelolaan Sumberdaya Air., http://psdal.lp3es.or.id/opini.html 
Olson, Mancur., 1971., The Logic of Collective Action., Cambridge - Harvard University Press.

Pratikno., 2004 Format Kelembagaan Kerjasama Antar daerah Kartamantul”, Yogyakarta Urban Quality GTZ dan Sekber Kartamantul

Pratikno (ed).,2007, Kerjasama Antar Daerah: Kompleksitas dan Tawaran Format Kelembagaan; Yogyakarta - Polokda JIP UGM

Pustra, Dep. Pekerjaan Umum: (2007), Kajian Reformasi Badan Regulator di Lingkungan Departemen Pekerjaan Umum, Jakarta - Pustra Dep. Pekerjaan Umum

Rosen, E.D. 1993. Improving Public Sector Productivity: Concept and Practice. London: Sage Publications, International Educational and Professional Publisher

Sekber Kartamantul, 2006, Membangun Kawasan Terpadu Perkotaan Kartamantul dengan Semangat Kebersamaan; Laporan Kegiatan Tahun 2005, Yogyakarta

Sinaga; Murbanto., 2006. Model Kerjasama Antar Daerah dalam Pembiayaan Pembangunan Daerah, Medan - USU Repository 2006

Kompas, “Kartamantul Anggarkan Rp 1,7 Miliar”, ed. 24 Maret 2007

Kompas, 25 April 2009, Laporan Khusus

www.kartamantul.pemda-diy.go.id/, 31 mei 2007

UU no 32 tahun 2004, Pemerintahan Daerah

UU no 22 Tahun 1999, Perimbangan Keuangan Pusat da Daerah

PP No 50 Tahun 2007; Tata Cara Kerjasama Daerah

Permendagri No 23; Petunjuk Teknis Kerjasama Daerah

Biro Pusat Statistik, 2011

16 Jurnal Maksipreneur, Vol. II, No. 2, Juni 2013 